\title{
"Standard Care" in Cancer Clinical Trials: An Analysis of Care Provided to Women in the Control Arms of Breast Cancer Clinical Trials
}

\author{
Rachel F. Dear, MBBS, PhDa; Kevin McGeechan, MSc, MBio, PhDº; Megan B. Barnet, MBBSa; \\ Alexandra L. Barratt, MBBS, MPH, PhD ${ }^{\mathrm{b}}$; and Martin H.N. Tattersall, MDa
}

\begin{abstract}
Background: For trials to validly evaluate new treatments, comparison against the best existing alternative treatment is essential. We reviewed the care provided to women in control arms of breast cancer clinical trials to estimate the proportion consistent with the standard of care as defined in clinical guidelines. Methods: We analyzed phase III randomized controlled breast cancer trials comparing drug treatments with "standard care," enrolling between 2004 and 2014, and registered on ClinicalTrials.gov. Our primary outcome was the proportion of trials in which treatment in the control arm was consistent with concurrent NCCN Guidelines. A secondary analysis assessed trials recruiting outside the United States that provided control group therapy not consistent with NCCN Guidelines, comparing them with the German Gynecological Oncology Group (AGO) guidelines. We assessed associations between the primary outcome and a priori selected trial characteristics. Results: This study included 210 trials that recruited 229,182 women worldwide; $29 \%$ of trials (60/210) did not provide control group treatment that was consistent with NCCN Guidelines. For trials not recruiting in the United States, results were similar; in $21 \%$ of trials, control arm treatment was inconsistent with both AGO and NCCN Guidelines. Factors significantly associated with offering control arm treatment that were inconsistent with guidelines were time period (later trials were less likely to be consistent), breast cancer stage and type (trials in early-stage breast cancer and estrogen receptor-negative disease were less likely consistent), and recruitment in $\geq 4$ countries and recruitment outside the United States. Conclusions: To ensure that clinical trials achieve their goal of obtaining the best information to guide patient treatment, the question of how investigators chose and describe "standard care" for control arm participants warrants further investigation.
\end{abstract}

Clinical trials are carefully designed and expensive experiments. It is scientifically and ethically important that these trials, which help define best practice for future patients, are well designed to clearly delineate the place of a new treatment alongside current standard practice. Without careful attention to trial design, including an appropriate control arm comparator, trials may produce misleading results and waste research resources. ${ }^{1}$

From a'Sydney Medical School, The University of Sydney, Chris O'Brien Lifehouse, and 'bydney School of Public Health, Edward Ford Building, The University of Sydney, Sydney, Australia.

Submitted November 25, 2016; accepted for publication April 28, 2017.

The authors have disclosed that they have no financial interests, arrangements, affiliations, or commercial interests with the manufacturers of any products discussed in this article or their competitors.
Concerns have been raised about the use of inappropriate comparators in clinical trials. ${ }^{2,3}$ An inappropriate comparator, such as a drug or dose that is less effective than standard treatment, may result in a new treatment appearing more effective than it really is. ${ }^{4}$ Another type of inappropriate comparator is one that may not be inferior, but is not proven or accepted as standard care, which will result in outcomes that are difficult to interpret and implement in the context of multiple

Author contributions: Study concept and design, data acquisition, data analysis and interpretation, manuscript preparation, critical revision, and approval of final manuscript: All authors. Guarantor of paper: Dear. Correspondence: Rachel F. Dear, MBBS, PhD, Sydney Medical School, The University of Sydney, Chris O'Brien Lifehouse, 119-143 Missenden Road, Camperdown NSW 2050, Sydney, Australia.

E-mail: Rachel.dear@sydney.edu.au 
standards across multiple trials. Inconsistency in choice of control arm undermines the quality of evidence generated by clinical trials, which in turn impacts systematic reviews, the development of clinical practice guidelines (CPGs), and planning of future trials.

The Declaration of Helsinki emphasizes that the "benefits, risks, burdens, and effectiveness of a new method should be tested against those of the best current prophylactic, diagnostic, and therapeutic methods." High-quality CPGs should represent a reliable source of information about best current practice and serve as a benchmark for standard care at the time they are written. As such, CPGs may help inform the design of control arms of randomized trials that seek to advance that benchmark. An example of high-quality CPGs for cancer treatment are the NCCN Clinical Practice Guidelines in Oncology (NCCN Guidelines), which are continuously updated to reflect new data. ${ }^{6}$ They are used extensively by clinicians in the United States and other countries, including China, Japan, Latin American, the Middle East, and Africa.

To determine the proportion of randomized clinical trials (RCTs) that use an appropriate comparator, we investigated phase III RCTs testing a drug intervention against standard care. We assessed how many of these trials provided control groups that adhered to standard care in the concurrent NCCN Guidelines. Worldwide, breast cancer is the most commonly researched cancer, accounting for the highest proportion of clinical trials, ${ }^{7}$ and therefore is an ideal group to analyze consistency of control arm care.

Specifically, we aimed to estimate the proportion of phase III RCTs of novel drug regimens for breast cancer in which control group participants received treatment at the time of trial initiation that was consistent with the NCCN Guidelines for Breast Cancer, and to explore heterogeneity according to prespecified subgroups, including time period, location, industry sponsorship, type of subjects, and treatments tested.

\section{Methods}

Our search strategy used the following fields in the advanced search engine of ClinicalTrials.gov: recruitment: "all studies"; study results: "all studies"; study type: "interventional studies"; condition: "breast cancer"; gender: "studies with female participants"; age group: "adult and senior"; "phase III"; and "first received from 01/01/2004 to 01/01/2014." The data fields from this search were then exported from ClinicalTrials.gov into Microsoft Excel.

A Microsoft Access database was used to collect the information required for this study. Each trial was required to meet 5 inclusion criteria: (1) studied women with breast cancer, (2) was a phase III RCT, (3) recruited patients from any countries in the world, (4) the control arm used drugs to treat breast cancer (chemotherapy, endocrine therapy, and/or targeted therapy), and (5) the trial was first received (first registered) by ClinicalTrials.gov between January 1, 2004, and January 1, 2014.

We used the NCCN Guidelines for Breast Cancer to determine whether the control group received the standard of care. There were 24 relevant NCCN Guidelines in the period of this study from 2004 to 2014. Treatment given in the control arm of each trial was compared with the standard of care as defined by the NCCN Guideline corresponding to the trial start date on ClinicalTrials.gov. Control arms were categorized as including chemotherapy, endocrine therapy, and/or targeted therapy. The control arm was then defined as either "standard" or "not standard" according to whether it used the NCCNrecommended chemotherapy, endocrine therapy, and/or targeted therapy. The control arm was deemed standard if it matched either the NCCN "preferred regimen" or "other regimen." The control arm was determined to be "standard" if both the drug dose and schedule matched the NCCN Guidelines recommendations. Trials were categorized as "not standard" if they were not included in the recommendations listed by the NCCN Guidelines (see supplemental eTable 1; available with this article at INCCN.org). Trials that included both estrogen receptor (ER)-positive and ER-negative disease were trials of chemotherapy or targeted therapies, thus we used the NCCN Guidelines regarding the use of these treatment types. The control group of some RCTs tested more than one type of drug treatment (eg, chemotherapy and targeted therapy) and all drug treatments tested in the trial needed to match the NCCN Guideline recommendations to be considered standard. In trials with multiple control arms, all arms had to satisfy the above criteria to confer a designation of "standard." Two authors (R.F.D., 
Are Cancer Trial Control Arms Standard?

M.B.B.) independently extracted data from half of the trials each. To ensure consistency, first they separately extracted data for the same 20 trials and compared results; there was $>90 \%$ concordance with the data fields collected. Differences were discussed and resolved to further standardize assessments made about each trial.

The primary outcome assessed was the proportion of trials whose control arm was consistent with standard of care defined by the NCCN Guidelines. In the context of breast cancer care, although the NCCN Guidelines are the most widely used internationally, evidence-based guidelines are also produced by the German Gynecological Oncology Group (AGO) that overall reflect a European (vs United States) perspective on breast cancer management. ${ }^{8,9}$ To allow for this variation in clinical practice, we therefore conducted a secondary analysis of trials recruiting outside the United States that provided control group therapy not consistent with NCCN Guidelines, comparing them with the AGO guidelines.

Using Pearson's chi-square tests and a modified Poisson regression approach, we assessed the association between the primary outcome and the variables including year of trial start, industry sponsorship, use of blinding, extent of breast cancer, HER2 receptor status, ER status, therapy type, number of countries of recruitment, and whether the trial was recruiting in the United States. ${ }^{10}$ All variables were included in the Poisson model, which provided estimated prevalence ratios. Pearson's chi-square and Fisher exact tests were used to assess association among the subgroups defined by type of treatment in the control arm: chemotherapy, endocrine therapy, or targeted therapy. We used Fisher exact test if $>20 \%$ of the expected counts in a table were $<5$. We described reasons why the control group was not deemed standard.

\section{Results}

\section{Study Population}

A total of 715 trials were extracted from ClinicalTrials.gov. Of these, 500 did not meet inclusion criteria, most because they did not use a drug intervention (80\%; 400/500). Trials may have been excluded for more than one reason (Figure 1).

Characteristics of the 215 eligible trials are detailed in Table 1. The largest proportion of trials started between 2008 and 2011, and almost half were

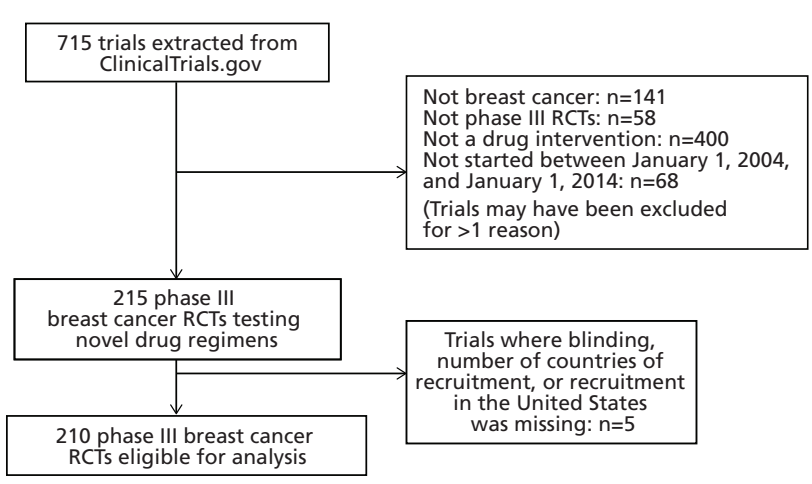

Figure 1. Randomized breast cancer trials extracted from ClinicalTrials.gov and eligible for analysis.

Abbreviation: RCTs, randomized controlled trials.

sponsored by industry. Most trials did not use blinding. Half were in the setting of metastatic breast cancer, almost one-quarter included only HER2-positive disease, and almost one-third included only ER-positive breast cancer. Most trials were only recruiting in one country, with $40 \%$ recruiting in the United States.

Of the 215 randomized breast cancer trials that met inclusion criteria, 210 were eligible for analysis; 5 trials were excluded because blinding, number of countries of recruitment, or recruitment in the United States was missing (Figure 1).

\section{Analysis}

Most trials (71\%; 150/210) provided control group care consistent with contemporaneous NCCN Guidelines, but almost one-third of randomized breast cancer trials $(29 \%$; 60/210) did not (Table $2)$. In total, there were 68,784 patients enrolled in trials that were not offering control group care consistent with the guidelines. In comparison, there were 160,398 patients enrolled in trials that had control group care consistent with the guidelines.

Results of our univariate model are shown in Table 2 and Figure 2. Factors that remained significantly consistent with NCCN Guidelines in the multivariable model were the trial start date, extent of breast cancer, ER status, number of countries of recruitment, and whether there was trial recruitment in the United States (Table 2, Figure 3). It was less likely for the control arm to be consistent in trials that began in 2012-2014, involved women with early-stage breast cancer, involved $\geq 4$ countries of recruitment, or if the trial was not recruiting in the United States (Table 2, Figure 3). Randomized breast cancer trials 
Dear et al

\begin{tabular}{|c|c|}
\hline Characteristics of Breast Cancer Trials & n (\%) \\
\hline \multicolumn{2}{|l|}{ Year trial started } \\
\hline 2004-2007 & $81(38)$ \\
\hline 2008-2011 & $87(40)$ \\
\hline 2012-2014 & $47(22)$ \\
\hline \multicolumn{2}{|l|}{ Industry-sponsored } \\
\hline Yes & $102(47)$ \\
\hline No & $113(53)$ \\
\hline \multicolumn{2}{|l|}{ Use of blinding } \\
\hline Blinded & $53(25)$ \\
\hline Not blinded & $159(74)$ \\
\hline Not clear & $3(1)$ \\
\hline \multicolumn{2}{|l|}{ Extent of breast cancer } \\
\hline Early & $107(50)$ \\
\hline Metastatic & $108(50)$ \\
\hline \multicolumn{2}{|l|}{ HER2 receptor status } \\
\hline Negative & 77 (36) \\
\hline Positive & $55(26)$ \\
\hline Both & $56(26)$ \\
\hline Not reported & $27(13)$ \\
\hline \multicolumn{2}{|l|}{ ER status } \\
\hline Negative & $13(6)$ \\
\hline Positive & $66(31)$ \\
\hline Both & $132(61)$ \\
\hline Not reported & $4(2)$ \\
\hline \multicolumn{2}{|l|}{ Countries of recruitment, $\mathrm{n}$} \\
\hline 1 & $124(58)$ \\
\hline 2 or 3 & $17(8)$ \\
\hline$\geq 4$ & $73(34)$ \\
\hline Not reported & $1(0)$ \\
\hline \multicolumn{2}{|l|}{ Recruiting in United States } \\
\hline No & $129(60)$ \\
\hline Yes & $85(40)$ \\
\hline Not reported & $1(0)$ \\
\hline
\end{tabular}

Abbreviation: ER, estrogen receptor.

that included ER-positive disease were more likely to use control arms consistent with the guidelines.

The most common reason that a control arm regimen was inconsistent was because it was not included in the NCCN Guidelines (58\%; 35/60). The remaining trials $(42 \% ; 25 / 60)$ used a regimen available in the NCCN Guidelines but not at the standard dose and/or schedule (supplemental eTable 1). The recommended dose was not used in 15 trials
(25\%); of these, 7 trials used lower-than-recommended doses (Table 3 ). These 7 trials proposed to enroll a total of 3,440 patients.

Among trials recruiting in the United States, the control arm was not considered standard in 11 of $83(13 \%)$ - a much lower proportion than the overall cohort $(60 / 210 ; 29 \%)$ (Table 4$)$. Of these 11 trials, 6 used control arm care that was not in the NCCN Guidelines. For example, in ClinicalTrials.gov identifier NCT00320385, which enrolled women with HER2-positive metastatic breast cancer previously treated with trastuzumab, the intervention was trastuzumab and lapatinib and the control was lapatinib monotherapy at $1,500 \mathrm{mg}$ orally daily; lapatinib monotherapy is not recommended in the guidelines. NCCN Guidelines recommend combination with capecitabine chemotherapy, which is consistent with RCT evidence. ${ }^{11}$ Another 5 trials used a different dose and/or schedule from the NCCN Guidelines. For example, in trial NCT00193726, which enrolled women with metastatic breast cancer, the intervention arm was combination chemotherapy (doxorubicin and docetaxel) and the control arm was docetaxel, 75 $\mathrm{mg} / \mathrm{m}^{2}$ intravenously on day 1 cycled every 21 days. The NCCN Guidelines recommend single-agent docetaxel at a dose of 80 to $100 \mathrm{mg} / \mathrm{m}^{2}$ intravenously day 1 cycled every 21 days (see Table 3 ).

A higher proportion of trials that recruited exclusively outside of the United States were not consistent with the NCCN Guidelines (39\%; 49/127) versus 11 of 83 trials $(13 \%)$ recruiting in the United States (Table 4). Of the 49 trials not consistent with NCCN Guidelines and not recruiting in the United States, 15 were consistent with the contemporaneous AGO guidelines and 34 were not. Therefore, for 45 of 210 trials in total $(21 \%)$, the control arm was not consistent with either guideline, allowing for compliance with the AGO guidelines for trials recruiting exclusively outside the United States. The 15 trials that were consistent with AGO, but not NCCN Guidelines, were all in earlystage breast cancer. Of these, 9 used a control group of epirubicin and cyclophosphamide followed by a taxane (either paclitaxel or docetaxel). The point of discordance with the NCCN Guidelines was the choice of anthracycline combined with cyclophosphamide before a taxane; NCCN recommends doxorubicin rather than epirubicin in this regimen. 
Are Cancer Trial Control Arms Standard?

\begin{tabular}{|c|c|c|c|c|c|}
\hline & \multicolumn{2}{|c|}{ Control Arm Standard } & \multirow{2}{*}{$\begin{array}{l}\text { Chi-Square } \\
P \text { Value }\end{array}$} & \multirow{2}{*}{$\begin{array}{l}\text { Adjusted }{ }^{\mathrm{b}} \text { Prevalence Ratio } \\
\qquad(95 \% \mathrm{Cl})\end{array}$} & \multirow{2}{*}{$\begin{array}{c}\text { Adjusted } \\
P \text { Value }\end{array}$} \\
\hline & Yes & No & & & \\
\hline Total number of trials, $\mathrm{n}(\%)$ & $150(71)$ & $60(29)$ & & & \\
\hline Year of trial start date, $\mathrm{n}(\%)$ & & & .026 & & .012 \\
\hline 2004-2007 & $61(79)$ & $16(21)$ & & $1.01(0.85,1.20)$ & \\
\hline 2008-2011 & $63(72)$ & $24(28)$ & & 1 (ref) & \\
\hline 2012-2014 & $26(57)$ & $20(43)$ & & $0.69(0.54,0.90)$ & \\
\hline Industry-sponsored, n (\%) & & & .013 & & .59 \\
\hline Yes & $81(79)$ & $21(21)$ & & 1 (ref) & \\
\hline No & $69(64)$ & $39(36)$ & & $0.94(0.77,1.16)$ & \\
\hline Use of blinding, $n(\%)$ & & & .15 & & .36 \\
\hline Blinded & $42(79)$ & $11(21)$ & & 1 (ref) & \\
\hline Not blinded & $108(69)$ & $49(31)$ & & $1.09(0.91,1.30)$ & \\
\hline Extent of breast cancer, $\mathrm{n}(\%)$ & & & .0001 & & .0004 \\
\hline Early & $61(59)$ & $42(41)$ & & $0.71(0.59,0.86)$ & \\
\hline Metastatic & $89(83)$ & $18(17)$ & & 1 (ref) & \\
\hline HER2 receptor status, ${ }^{c} n(\%)$ & & & .66 & & .080 \\
\hline Negative & $54(72)$ & $21(28)$ & & 1 (ref) & \\
\hline Positive & $40(75)$ & $13(24)$ & & $1.12(0.90,1.39)$ & \\
\hline Both & $56(68)$ & $26(32)$ & & $0.86(0.71,1.05)$ & \\
\hline ER status, $\mathrm{c} n(\%)$ & & & .0059 & & $<.0001$ \\
\hline Negative & $7(58)$ & $5(42)$ & & $0.63(0.38,1.04)$ & \\
\hline Positive & $56(86)$ & $9(14)$ & & 1 (ref) & \\
\hline Both & $87(65)$ & $46(35)$ & & $0.64(0.54,0.77)$ & \\
\hline Countries of recruitment, $n(\%)$ & & & .021 & & .050 \\
\hline 1 & $78(65)$ & $42(35)$ & & 1 (ref) & \\
\hline 2 or 3 & $16(94)$ & $1(6)$ & & $1.10(0.87,1.39)$ & \\
\hline$\geq 4$ & $56(77)$ & $17(23)$ & & $0.82(0.65,1.03)$ & \\
\hline Recruiting in United States, $\mathrm{n}(\%)$ & & & $<.0001$ & & .0007 \\
\hline No & $78(61)$ & 49 (39) & & $0.72(0.60,0.87)$ & \\
\hline Yes & $72(87)$ & $11(13)$ & & 1 (ref) & \\
\hline
\end{tabular}

Abbreviation: ER, estrogen receptor.

aExcludes trials where blinding, number of countries of recruitment, or recruitment in the United States was missing.

bAll variables in the table are included in the multivariable regression model.

cNot reported is assumed to include both factors.

The remaining $6 \mathrm{AGO}$-consistent/NCCN-nonconsistent trials involved adjuvant endocrine therapy; 2 used a gonadotropin-releasing hormone (GnRH) agonist and tamoxifen in premenopausal women, and 4 used tamoxifen in postmenopausal women. A GnRH agonist with tamoxifen is included in the AGO guidelines for premenopausal women with early-stage breast cancer; the NCCN Guidelines recommend tamoxifen alone. The AGO guidelines recommend either tamoxifen or an aromatase inhibitor (AI) for postmenopausal women with early-stage breast cancer; the NCCN Guidelines recommend an AI unless there are specific contraindications to this class of medication.

\section{Discussion}

\section{Statement of Key Findings}

Although appropriate comparators in RCTs have been the subject of comment and concern for some time, this is the first study to address this question empirically using a large set of trials over a long period. In cancer trials, which account for the highest proportion of registered clinical trials on ClinicalTrials.gov, approximately one-third (29\%) of phase III 
Dear et al

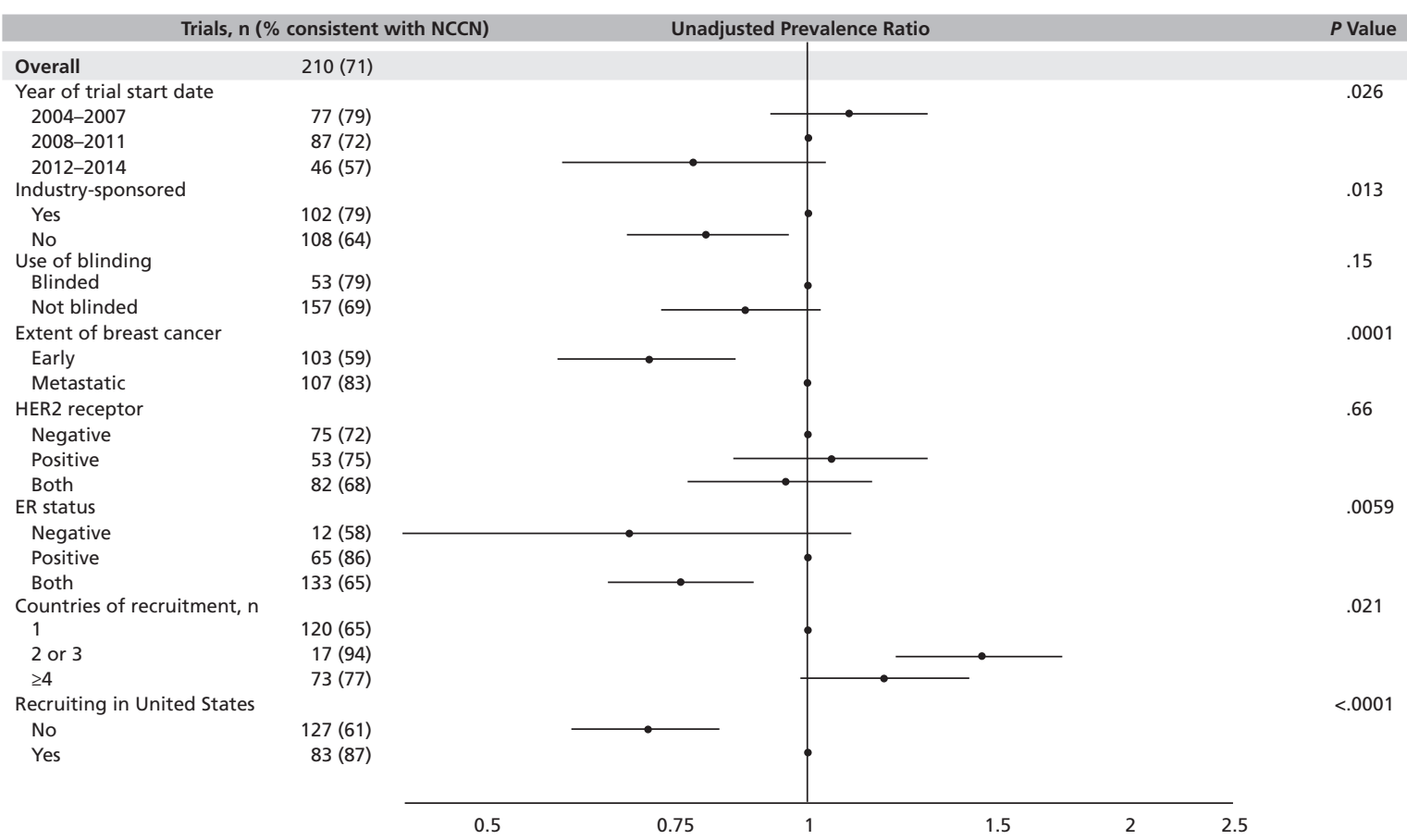

Figure 2. Association between trial characteristics and whether the control arm of randomized breast cancer trials is standard of care $(n=210)$, demonstrating unadjusted prevalence ratios.

Abbreviation: ER, estrogen receptor.

trials between 2004 and 2014 did not use a control arm consistent with the relevant NCCN Guidelines.

It was less likely for the control arm to be consistent with NCCN Guidelines if the trial was not recruiting in the United States, recruited in $\geq 4$ countries, began between 2012 and 2014, or if the trial involved women with early-stage breast cancer. Trials recruiting exclusively outside the United States were more likely to have a control arm not consistent with NCCN Guidelines. Of those, most were also not consistent with a major European guideline (the AGO guidelines). Trials including women with ER-positive breast cancer were more likely to be consistent with the guidelines.

An important distinction must be made between standard care in clinical practice and clinical trials. In the clinic, each patient will have a specific set of factors that influence treatment, such as age, performance status, and comorbidities. In this situation, it is appropriate to consider a range of acceptable treatment options and apply them to the patient's circumstances. In contrast, clinical trials have strict protocols covering all aspects of patient recruitment, randomization, follow-up, and assessment of outcome; this is essential to ensure quality results.
This robust framework must extend to selection of the control arm to enable valid comparison with the intervention arm. Ethically, it is also crucial that patients entering clinical trials receive the most appropriate standard of care; patients who donate their time and energy to advance clinical knowledge for others deserve no less.

\section{Study Strengths and Limitations}

An important strength of our study is that we used a large set of clinical trials conducted over a period of 10 years to test our research questions. Trials registered with ClinicalTrials.gov constitute the largest proportion of trials on the WHO International Clinical Trials Registry Platform ${ }^{12}$ (77\%), and therefore it is likely that the breast cancer clinical trials are representative of trials internationally.

An additional strength is that we were able to make a meaningful comparison of trials registered with a US-based registry (ClinicalTrials.gov) and the US-developed NCCN Guidelines. The NCCN Guidelines are the most commonly used oncology guidelines in the world, are readily available on the NCCN Web site, and are the only guidelines to be updated multiple times per year using a robust and transparent process. Although concerns have been 
Are Cancer Trial Control Arms Standard?

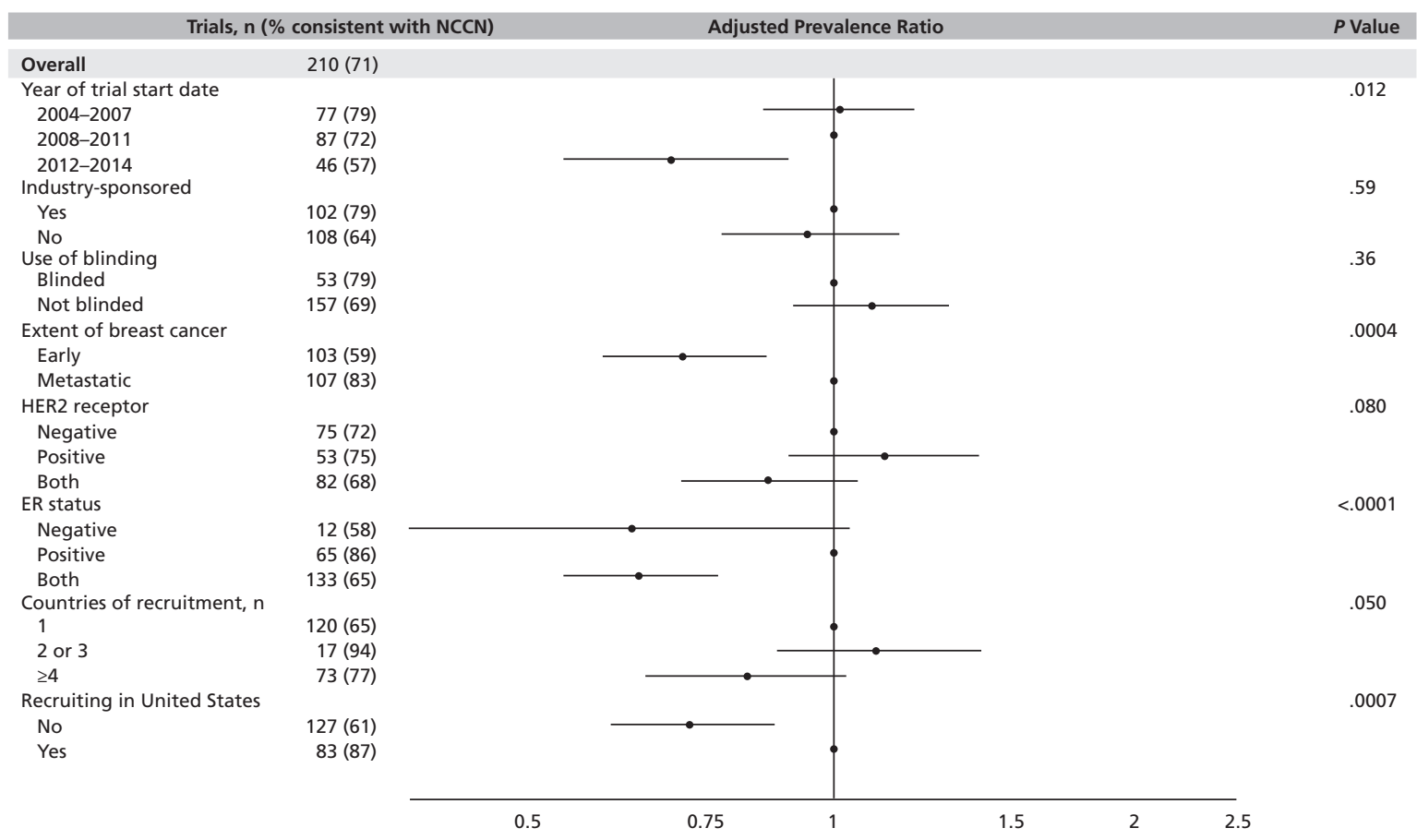

Figure 3. Association between trial characteristics and whether the control arm of randomized breast cancer trials is standard of care ( $\mathrm{n}=210$ ), demonstrating adjusted prevalence ratios.

Abbreviation: ER, estrogen receptor.

raised about the quality of CPGs, ${ }^{13-16}$ conflicts of interest are declared in the NCCN Guidelines and every effort is made to ensure that evidence-based and consensus-based recommendations are documented.

Worldwide, there are regional variations in oncology practice that may be due to the use of local guidelines. To allow for this variation, we also compared control arm treatment in trials not recruiting in the United States with the major European oncology guidelines. There remained 45 of 210 trials (21\%) that were not consistent with either guideline.

We stringently compared therapy offered to control group participants with therapy recommended by the NCCN Guidelines so we could objectively and reliably apply our reference standard to all trials assessed. We acknowledge that there are some scenarios in which trialists may consider this too stringent. One scenario is trials that compare 2 regimens with different agents but that need to control for the duration of the regimen. For example, in the Hellenic Cooperative Oncology Group trial (ClinicalTrials.gov identifier: NCT00431080), the control group used 4 cycles each of FEC (5-fluorouracil, epirubicin, and cyclophosphamide) and docetaxel rather than the standard 3 cycles, so it could be compared fairly with the intervention arm that used FEC for 4 cycles followed by dose-dense paclitaxel for 4 cycles. Another scenario is exemplified by trial NCT00320385, wherein it might be considered reasonable to use a control arm of lapatinib alone rather than the standard lapatinib/capecitabine when comparing it with combination trastuzumab/lapatinib, because this trial was testing a chemotherapy-free strategy. The final example is illustrated in trial NCT00938652, which compared a control arm of carboplatin/gemcitabine versus this combination plus iniparib in metastatic triple-negative breast cancer; although carboplatin/ gemcitabine was not included as a standard regimen in the relevant NCCN Guidelines, this may be considered a reasonable control group given that the intervention was testing iniparib with DNA-damaging chemotherapy. However, we argue that even minor deviations from guidelines increase the difficulty of combining data across trials in systematic reviews and meta-analyses, and, like all deviations, potentially undermine the research evidence base generated by ongoing clinical trials. ${ }^{17}$

Despite this analysis, we acknowledge that all trials conducted globally cannot be expected to follow US or European guidelines, because different 
Dear et al

\section{Table 3. Deviations from NCCN Guideline-Recommended Therapy}

\begin{tabular}{|c|c|c|c|}
\hline $\begin{array}{l}\text { ClinicalTrials.gov } \\
\text { Identifier }\end{array}$ & Trial Control Arm & NCCN Recommendation & NCCN Guideline ${ }^{a}$ \\
\hline NCT00091442 & Docetaxel, $75 \mathrm{mg} / \mathrm{m}^{2}$ IV day 1 cycled every 21 days & Docetaxel, $80-100 \mathrm{mg} / \mathrm{m}^{2}$ IV day 1 cycled every 21 days & v1.2004 \\
\hline NCT00431080 & $\begin{array}{l}\text { FEC (F: } 700 \mathrm{mg} / \mathrm{m}^{2} \text { IV day } 1 \text { cycled every } 28 \text { days for } 4 \text { cycles, } \\
\text { E: } 75 \mathrm{mg} / \mathrm{m}^{2} \text { IV day } 1 \text { cycled every } 14 \text { days for } 4 \text { cycles, C: } 700 \\
\mathrm{mg} / \mathrm{m}^{2} \text { IV day } 1 \text { cycled every } 28 \text { days for } 4 \text { cycles) followed by } \\
\text { docetaxel, } 75 \mathrm{mg} / \mathrm{m}^{2} \text { IV day } 1 \text { cycled every } 14 \text { days for } 4 \text { cycles }\end{array}$ & $\begin{array}{l}\text { FEC (F: } 500 \mathrm{mg} / \mathrm{m}^{2}, \mathrm{E}: 100 \mathrm{mg} / \mathrm{m}^{2}, \mathrm{C}: 500 \mathrm{mg} / \mathrm{m}^{2} \text { ) IV day } 1 \\
\text { cycled every } 21 \text { days for } 3 \text { cycles followed by docetaxel, } \\
100 \mathrm{mg} / \mathrm{m}^{2} \text { IV day } 1 \text { cycled every } 21 \text { days for } 3 \text { cycles }\end{array}$ & v1.2004 \\
\hline NCT00593697 & $\begin{array}{l}\text { Trastuzumab with docetaxel followed by FEC (F: } 700 \\
\mathrm{mg} / \mathrm{m}^{2} \text { IV day } 1 \text { cycled every } 28 \text { days for } 4 \text { cycles, E: } 75 \\
\mathrm{mg} / \mathrm{m}^{2} \text { IV day } 1 \text { cycled every } 14 \text { days for } 4 \text { cycles, C: } 700 \\
\mathrm{mg} / \mathrm{m}^{2} \text { IV day } 1 \text { cycled every } 28 \text { days for } 4 \text { cycles) }\end{array}$ & $\begin{array}{l}\text { Trastuzumab with docetaxel followed by FEC (F: } 600 \\
\mathrm{mg} / \mathrm{m}^{2}, \mathrm{E}: 60 \mathrm{mg} / \mathrm{m}^{2}, \mathrm{C}: 600 \mathrm{mg} / \mathrm{m}^{2} \text { ) IV day } 1 \text { cycled every } \\
21 \text { days for } 3 \text { cycles }\end{array}$ & v1.2008 \\
\hline NCT00615602 & $\begin{array}{l}\text { Trastuzumab with docetaxel followed by FEC (F: } 700 \mathrm{mg} / \\
\mathrm{m}^{2} \text { IV day } 1 \text { cycled every } 28 \text { days for } 4 \text { cycles, E: } 75 \mathrm{mg} / \mathrm{m}^{2} \text { IV } \\
\text { day } 1 \text { cycled every } 14 \text { days for } 4 \text { cycles, C: } 700 \mathrm{mg} / \mathrm{m}^{2} \text { IV day } 1 \\
\text { cycled every } 28 \text { days for } 4 \text { cycles) }\end{array}$ & $\begin{array}{l}\text { Trastuzumab with docetaxel followed by FEC (F: } 600 \\
\mathrm{mg} / \mathrm{m}^{2}, \mathrm{E}: 60 \mathrm{mg} / \mathrm{m}^{2}, \mathrm{C}: 600 \mathrm{mg} / \mathrm{m}^{2} \text { ) IV day } 1 \text { cycled every } \\
21 \text { days for } 3 \text { cycles }\end{array}$ & v1.2004 \\
\hline NCT01095003b & $\begin{array}{l}\text { Capecitabine, } 825 \mathrm{mg} / \mathrm{m}^{2} \text { PO twice daily days } 1-14 \text { cycled } \\
\text { every } 21 \text { days }\end{array}$ & $\begin{array}{l}\text { Capecitabine, } 1,000-1,250 \mathrm{mg} / \mathrm{m}^{2} \text { PO twice daily days } 1-14 \\
\text { cycled every } 21 \text { days }\end{array}$ & v1.2009 \\
\hline NCT01126138 & $\begin{array}{l}\text { Docetaxel, } 75 \mathrm{mg} / \mathrm{m}^{2} \text { IV day } 1 \text { cycled every } 21 \text { days } \\
\text { for } 6 \text { cycles with capecitabine, } 1,000 \mathrm{mg} / \mathrm{m}^{2} \text { PO twice daily } \\
\text { days } 1-14 \text { cycled every } 21 \text { days for } 6 \text { cycles followed by } \\
\text { capecitabine, } 1,000 \mathrm{mg} / \mathrm{m}^{2} \text { PO twice daily days } 1-14 \\
\text { cycled every } 21 \text { days maintenance }\end{array}$ & $\begin{array}{l}\text { Docetaxel, } 75 \mathrm{mg} / \mathrm{m}^{2} \text { IV day } 1 \text { cycled every } 21 \text { days with } \\
\text { capecitabine, } 950 \mathrm{mg} / \mathrm{m}^{2} \text { PO twice daily days } 1-14 \text { cycled } \\
\text { every } 21 \text { days until progression }\end{array}$ & v2.2010 \\
\hline NCT01200212 & $\begin{array}{l}\text { Bevacizumab, } 15 \mathrm{mg} / \mathrm{kg} \text { IV day } 1 \text { cycled every } 21 \text { days with } \\
\text { paclitaxel, } 80 \mathrm{mg} / \mathrm{m}^{2} \text { IV day } 1 \text { cycled weekly }\end{array}$ & $\begin{array}{l}\text { Bevacizumab, } 10 \mathrm{mg} / \mathrm{kg} \text { IV days } 1 \text { and } 15 \text { cycled every } 28 \\
\text { days with paclitaxel, } 90 \mathrm{mg} / \mathrm{m}^{2} \text { IV day } 1,8 \text {, and } 15 \text { cycled } \\
\text { every } 28 \text { days }\end{array}$ & v1.2009 \\
\hline NCT01204437 & $\begin{array}{l}\text { CMF (C: } 500 \mathrm{mg} / \mathrm{m}^{2}, \mathrm{M}: 40 \mathrm{mg} / \mathrm{m}^{2}, \mathrm{~F}: 600 \mathrm{mg} / \mathrm{m}^{2} \text { ) IV days } 1 \\
\text { and } 8 \text { cycled every } 28 \text { days for } 6 \text { cycles }\end{array}$ & $\begin{array}{l}\text { CMF (C: } 100 \mathrm{mg} / \mathrm{m}^{2} \text { PO days } 1-14, \mathrm{M}: 40 \mathrm{mg} / \mathrm{m}^{2} \text { IV days } 1 \\
\text { and } 8, \mathrm{~F}: 600 \mathrm{mg} / \mathrm{m}^{2} \text { IV days } 1 \text { and } 8 \text { ) cycled every } 28 \text { days } \\
\text { for } 6 \text { cycles }\end{array}$ & v1.2009 \\
\hline NCT01303679b & $\begin{array}{l}\text { Bevacizumab, } 10 \mathrm{mg} / \mathrm{kg} \text { IV days } 1 \text { and } 15 \text { cycled every } 28 \\
\text { days with paclitaxel, } 80 \mathrm{mg} / \mathrm{m}^{2} \text { IV day } 1,8 \text {, and } 15 \text { cycled } \\
\text { every } 28 \text { days }\end{array}$ & $\begin{array}{l}\text { Bevacizumab, } 10 \mathrm{mg} / \mathrm{kg} \text { IV days } 1 \text { and } 15 \text { cycled every } 28 \\
\text { days with paclitaxel, } 90 \mathrm{mg} / \mathrm{m}^{2} \text { IV day } 1,8 \text {, and } 15 \text { cycled } \\
\text { every } 28 \text { days }\end{array}$ & v2.2011 \\
\hline NCT01622361 & $\begin{array}{l}\text { AC (A: } 60 \mathrm{mg} / \mathrm{m}^{2}, \text { C: } 600 \mathrm{mg} / \mathrm{m}^{2} \text { ) IV day } 1 \text { cycled every } 21 \text { days } \\
\text { for } 4 \text { cycles followed by docetaxel, } 75 \mathrm{mg} / \mathrm{m}^{2} \text { IV day } 1 \text { cycled } \\
\text { every } 21 \text { days for } 4 \text { cycles }\end{array}$ & $\begin{array}{l}\text { AC (A: } 60 \mathrm{mg} / \mathrm{m}^{2}, \text { C: } 600 \mathrm{mg} / \mathrm{m}^{2} \text { ) IV day } 1 \text { cycled every } 21 \\
\text { days for } 4 \text { cycles followed by docetaxel, } 100 \mathrm{mg} / \mathrm{m}^{2} \text { IV day } \\
1 \text { cycled every } 21 \text { days for } 4 \text { cycles }\end{array}$ & v1.2012 \\
\hline NCT01642771 & $\begin{array}{l}\text { Docetaxel, } 75 \mathrm{mg} / \mathrm{m}^{2} \text { IV day } 1 \text { cycled every } 21 \text { days } \\
\text { for } 3 \text { cycles followed by FEC (F: } 500 \mathrm{mg} / \mathrm{m}^{2} \text {, E: } 75 \\
\mathrm{mg} / \mathrm{m}^{2}, \text { C: } 500 \mathrm{mg} / \mathrm{m}^{2} \text { ) IV day } 1 \text { cycled every } 21 \text { days for } \\
3 \text { cycles }\end{array}$ & $\begin{array}{l}\text { FEC (F: } 500 \mathrm{mg} / \mathrm{m}^{2}, \mathrm{E}: 100 \mathrm{mg} / \mathrm{m}^{2}, \mathrm{C}: 500 \mathrm{mg} / \mathrm{m}^{2} \text { ) IV day } 1 \\
\text { cycled every } 21 \text { days for } 3 \text { cycles followed by docetaxel, } \\
100 \mathrm{mg} / \mathrm{m}^{2} \text { IV day } 1 \text { cycled every } 21 \text { days for } 3 \text { cycles }\end{array}$ & v1.2012 \\
\hline NCT01663727 & Paclitaxel, $90 \mathrm{mg} / \mathrm{m}^{2}$ IV days 1,8 , and 15 cycled every 28 days & Paclitaxel, 80 mg/m² IV weekly & v2.2012 \\
\hline NCT01917279 & $\begin{array}{l}\text { Capecitabine, } 1,000 \mathrm{mg} / \mathrm{m}^{2} \text { PO twice daily days } 1-14 \text { cycled } \\
\text { every } 21 \text { days with docetaxel, } 75 \mathrm{mg} / \mathrm{m}^{2} \text { day } 1 \text { cycled every } 21 \\
\text { days for up to } 6 \text { cycles }\end{array}$ & $\begin{array}{l}\text { Capecitabine, } 950 \mathrm{mg} / \mathrm{m}^{2} \text { PO twice daily days } 1-14 \text { cycled } \\
\text { every } 21 \text { days with docetaxel, } 75 \mathrm{mg} / \mathrm{m}^{2} \text { IV day } 1 \text { cycled } \\
\text { every } 21 \text { days until progression }\end{array}$ & v3.2013 \\
\hline NCT02000622 & $\begin{array}{l}\text { Capecitabine, } 2,500 \mathrm{mg} / \mathrm{m}^{2} \text { PO days } 1-14 \text { cycled every } 21 \\
\text { days OR vinorelbine, } 30 \mathrm{mg} / \mathrm{m}^{2} \text { IV days } 1 \text { and } 8 \text { cycled every } \\
21 \text { days, or eribulin, } 1.4 \mathrm{mg} / \mathrm{m}^{2} \text { IV days } 1 \text { and } 8 \text { cycled every } \\
21 \text { days }\end{array}$ & Vinorelbine, $25 \mathrm{mg} / \mathrm{m}^{2}$ IV day 1 cycled weekly & v1.2014 \\
\hline NCT02001506 & $\begin{array}{l}\text { AC IV cycled every } 21 \text { days for } 4 \text { cycles followed by docetaxel, } \\
75 \mathrm{mg} / \mathrm{m}^{2} \text { IV cycled every } 21 \text { days for } 4 \text { cycles }\end{array}$ & $\begin{array}{l}\text { AC IV cycled every } 21 \text { days for } 4 \text { cycles followed by } \\
\text { docetaxel, } 100 \mathrm{mg} / \mathrm{m}^{2} \text { IV cycled every } 21 \text { days for } 4 \text { cycles }\end{array}$ & v3.2012 \\
\hline
\end{tabular}

Abbreviations: A, adriamycin/doxorubicin; C, cyclophosphamide; E, epirubicin; F, 5-fluorouracil; G, gemcitabine; IV, intravenous; M, methotrexate; PO, per oral.

aNCCN Guideline version quoted is the one comparable to the trial's start date.

${ }^{b}$ Dose of drugs used in the control arm is lower than recommended by the NCCN Guidelines.

pharmacogenomic profiles of patient populations may influence toxicities locally. Using a "nonstandard" regimen may be reasonable in this circumstance, although the results would not be generalizable to other patient populations.

Some readers may question the choice of NCCN Guidelines as our reference standard for defining standard care for the control arms in the trials we assessed. We searched for guidance about how control group care should be chosen in RCTs and were surprised to find little available, although the importance of a fair comparator is widely acknowledged. The FDA and the Center for Medical Technology Policy (CMTP) ${ }^{18,19}$ note the critical importance of choice of an appropriate control arm for testing new treatments, and state that active control arm trials 
Are Cancer Trial Control Arms Standard?

\begin{tabular}{|c|c|c|c|c|}
\hline & \multicolumn{2}{|c|}{ Outside US } & \multicolumn{2}{|c|}{ Inside US } \\
\hline & $n$ & (\%) & $n$ & (\%) \\
\hline $\begin{array}{l}\text { Control arm is not } \\
\text { standard of care }\end{array}$ & 49 & 39 & 11 & 13 \\
\hline $\begin{array}{l}\text { Regimen not } \\
\text { in NCCN Guidelines }\end{array}$ & 29 & 23 & 6 & 7 \\
\hline $\begin{array}{l}\text { Dose and/or } \\
\text { schedule not } \\
\text { standard }\end{array}$ & 20 & 16 & 5 & 6 \\
\hline Total & 127 & & 83 & \\
\hline
\end{tabular}

are preferred over placebo trials (for ethical and scientific reasons). Investigators are advised that active care must be given to appropriate patients, at appropriate doses, and at an appropriate schedule to be interpretable and provide fair comparisons, but it is unclear how such judgements should be determined. We therefore think the NCCN Guidelines represent the best reference standard for appropriate care for the comparator arms of cancer clinical trials that we could have chosen. Of note, it is clear from our study that more careful study and guidance on how

\section{References}

1. Ioannidis JP, Greenland $S$, Hlatky MA, et al. Increasing value and reducing waste in research design, conduct, and analysis. Lancet 2014;383:166-175.

2. Abbasi $\mathrm{K}$. Blood on our hands: seeing the evil in inappropriate comparators. J R Soc Med 2013;106:1.

3. Dieppe P. Complicity theory: an explanation for the 'coxib problem'? J R Soc Med 2006;99:273-274.

4. Goldacre B. Bad Pharma: How Medicine is Broken, and How We Can Fix It, 1st ed. New York, NY: HarperCollins Publishers; 2012.

5. World Medical Association. WMA Declaration of Helsinki - Ethical Principles for Medical Research Involving Human Subjects. Available at: http://www.wma.net/en/30publications/10policies/b3/17c.pdf. Accessed July 20, 2017. Accessed August 4, 2017.

6. Gradishar WJ, Anderson BO, Balassanian R, et al. NCCN Clinical Practice Guidelines in Oncology. To view the most recent version of these guidelines, visit NCCN.org. Accessed July 20, 2017.

7. Dear RF, Barratt AL, McGeechan K, et al. Landscape of cancer clinical trials in Australia: using trial registries to guide future research. Med J Aust 2011;194:387-391.

8. Arbeitsgemeinschaft Gynäkologische Onkologie Breast Committee. Diagnosis and Treatment of Patients with Primary and Metastatic Breast Cancer. Version 16.1.0. Available at: https://www.ago-online. de/fileadmin/downloads/leitlinien/mamma/Maerz2016/en/Updated\%20 Guidelines_2016.pdf. Accessed July 20, 2017.

9. Kantelhardt EJ, Thomssen C. German recommendations for diagnosis and treatment of breast cancer 2008. What is new from the Breast Commission of the German Gynaecological Oncology Working Group (AGO)? Breast Care (Basel) 2008;3:93-99.

10. Zou G. A modified Poisson regression approach to prospective studies with binary data. Am J Epidemiol 2004;159:702-706 to choose appropriate comparators for active care trials would be very valuable to future investigators.

\section{Conclusions}

Our results raise serious concerns regarding the fact that almost $30 \%$ of contemporary breast cancer RCTs may be using an inappropriate comparator in the provision of "standard care" to control arm participants. Inappropriate comparators that deviate from best available care threaten the internal validity and applicability of the results of randomized trials. As such, they waste research resources, compromise the quality of future clinical guidelines, and potentially undermine clinical care and patient outcomes. That approximately one-third of breast cancer clinical trials may be flawed in this way is, we believe, unacceptable and requires urgent action. Trialists must ensure care offered to control arm participants is consistent with up-to-date, high-quality guidelines, or, if they plan to offer care that is inconsistent with guidelines, their choice needs to be clearly justified and described to the patients recruited to the trial.

11. Geyer CE, Forster J, Lindquist D, et al. Lapatinib plus capecitabine for HER2-positive advanced breast cancer. N Engl J Med 2006;355:27332743.

12. World Health Organisation. International Clinical Trials Registry Platform (ICTRP). Available at: http://apps.who.int/trialsearch/. Accessed July 20, 2017.

13. Davies E. Can you trust your clinical guidelines? BMJ 2013;346:44003.

14. Lenzer J. Why we can't trust clinical guidelines. BMJ 2013;346:f3830.

15. Medscape. The Virtues and Vices of the NCCN Guidelines. Available at: http://www.medscape.com/viewarticle/841572. Accessed July 20, 2017

16. Qaseem A, Forland F, Macbeth F, et al; for the Board of Trustees of the Guidelines International Network. Guidelines International Network: toward international standards for clinical practice guidelines. Ann Intern Med 2012;156:525-531.

17. Institute of Medicine (US) Committee on Standards for Developing Trustworthy Clinical Practice Guidelines; Graham R, Mancher M, Miller Wolman D, et al, eds. Clinical Practice Guidelines We Can Trust. Washington, DC: National Academies Press; 2011.

18. Guidance for Industry. E10 Choice of Control Group and Related Issues in Clinical Trials. Available at: https://www.fda.gov/downloads/drugs/ guidancecomplianceregulatoryinformation/guidances/ucm073139.pdf. Accessed July 20, 2017.

19. Sonnad S, Goldsack J, Mohr P, et al; for the Center for Medical Technology Policy. Pragmatic phase 3 pharmaceutical trials: recommendations for the design of clinical trials that are more informative for patients, clinicians and payers (September 2010). Available at: http://www.cmtpnet.org/docs/ resources/PCT3_EGD.pdf. Accessed July 20, 2017. 